\title{
The $\mathrm{Co}_{2} \mathrm{Al}_{9}$ Structure Type Revisited
}

\section{Magnus Boström*, Helge Rosner, Yurii Prots, Ulrich Burkhardt, and Yuri Grin}

Dresden, Max-Planck-Institut für Chemische Physik fester Stoffe

Received September 6th, 2004.

Dedicated to Professor Arndt Simon on the Occasion of his $65^{\text {th }}$ Birthday

Abstract. The centrosymmetric structure of $\mathrm{Co}_{2} \mathrm{Al}_{9}$ (space group $P 2_{1} / c$, Pearson symbol $m P 22$ ), the isotypic structures of $\mathrm{Rh}_{2} \mathrm{Al}_{9}$ and $\mathrm{Ir}_{2} \mathrm{Al}_{9}$ and the slightly distorted acentric structures of $\mathrm{Rh}_{2} \mathrm{Ga}_{9}$ and $\mathrm{Ir}_{2} \mathrm{Ga}_{9}$ (space group $P c$ ) were reinvestigated from single crystal $\mathrm{X}$-ray diffraction data. The structure of $\mathrm{Rh}_{2} \mathrm{Ga}_{9}$ represents a new structure type. The difference between the aluminides and the gal-

\section{Der Strukturtyp $\mathrm{Co}_{2} \mathrm{Al}_{9}$ erneut untersucht}

Inhaltsübersicht. Die zentrosymmetrische Struktur der Verbindung $\mathrm{Co}_{2} \mathrm{Al}_{9}$ (Raumgruppe $P 2_{1} / c$, Pearson-Symbol $m P 22$ ), die isotypen Strukturen $\mathrm{Rh}_{2} \mathrm{Al}_{9}$ und $\mathrm{Ir}_{2} \mathrm{Al}_{9}$, sowie die leicht verzerrten azentrischen Strukturen $\mathrm{Rh}_{2} \mathrm{Ga}_{9}$ und $\mathrm{Ir}_{2} \mathrm{Ga}_{9}$ (Raumgruppe $P c$ ) wurden auf der Basis der Einkristall-Röntgenbeugungsdaten erneut unter- lides originates in the details of atomic interactions investigated by the electron localization function and band structure calculations.

Keywords: Intermetallic compounds; crystal structure; chemical bonding

\section{Introduction}

Four representatives of the $\mathrm{Co}_{2} \mathrm{Al}_{9}$ structure type [1] have been found exclusively among aluminides and gallides of the cobalt group transition metals: $\mathrm{Rh}_{2} \mathrm{Al}_{9}, \mathrm{Ir}_{2} \mathrm{Al}_{9}$ [2], $\mathrm{Rh}_{2} \mathrm{Ga}_{9}$ and $\mathrm{Ir}_{2} \mathrm{Ga}_{9}$ [3]. Except for $\mathrm{Co}_{2} \mathrm{Al}_{9}$, none of the structures have previously been refined from single crystal or powder diffraction data. During an ongoing study of the binary compounds in the $\mathrm{Ir}-\mathrm{Ga}$ system, it was found that $\mathrm{Ir}_{2} \mathrm{Ga}_{9}$ is not correctly described as isotypic to $\mathrm{Co}_{2} \mathrm{Al}_{9}$. This prompted a detailed crystal structure re-investigation of all the five known compounds previously assigned to the $\mathrm{Co}_{2} \mathrm{Al}_{9}$ structure type.

\section{Experimental}

Single crystals of the aluminides $\mathrm{T}_{2} \mathrm{Al}_{9}(\mathrm{~T}=\mathrm{Co}, \mathrm{Rh}, \mathrm{Ir})$ were prepared starting from mixtures of the elements with nominal compositions (Table 1) corresponding to the equilibrium region between the relevant phase and its melt [4]. The mixtures were weld-sealed in tantalum containers fitted with tantalum filters, which were

* Dr. Magnus Boström

c/o Prof. Dr. Yuri Grin

Max-Planck-Institut für Chemische Physik fester Stoffe

Nöthnitzer Str. 40

D-01187 Dresden

FAX: 0351-4646-4002

e-mail: bostroem@cpfs.mpg.de

grin@cpfs.mpg.de sucht. $\mathrm{Rh}_{2} \mathrm{Ga}_{9}$ stellt einen neuen Strukturtyp dar. Der Unterschied zwischen den Aluminiden und den Galliden wird durch interatomare Wechselwirkungen verursacht, die mit Hilfe der ElektronenLokalisierung-Funktion und Bandstruktur-Berechnungen untersucht wurden.
Table 1 Preparation of the $\mathrm{T}_{2} \mathrm{Al}_{9}$ and $\mathrm{T}_{2} \mathrm{Ga}_{9}$ compounds $(\mathrm{T}=\mathrm{Co}$, Rh, Ir). Educts: Co, Chempur, 99.5\%; Rh, Chempur, $99.9 \%$; Ir, Lamprecht, $99.9 \%$; Al, Chempur, 99.99\%; Ga, Chempur, $99.999 \%$.

\begin{tabular}{|c|c|c|}
\hline Compound & Starting composition & Heat treatment \\
\hline $\mathrm{Co}_{2} \mathrm{Al}_{9}$ & $0.208 \mathrm{~g} \mathrm{Co} ; 0.826 \mathrm{~g} \mathrm{Al}\left(\mathrm{Co}_{0.103} \mathrm{Al}_{0.897}\right)$ & 8 days at $800^{\circ} \mathrm{C}$ \\
\hline $\mathrm{Rh}_{2} \mathrm{Al}_{9}$ & $0.158 \mathrm{~g} \mathrm{Rh} ; 0.378 \mathrm{~g} \mathrm{Al}\left(\mathrm{Rh}_{0.099} \mathrm{Al}_{0.901}\right)$ & 8 days at $800^{\circ} \mathrm{C}$ \\
\hline $\mathrm{Ir}_{2} \mathrm{Al}_{9}$ & $0.232 \mathrm{~g} \mathrm{Ir} ; 0.299 \mathrm{~g} \mathrm{Al}\left(\mathrm{Ir}_{0.098} \mathrm{Al}_{0.902}\right)$ & 7 days at $800^{\circ} \mathrm{C}$ \\
\hline $\mathrm{Rh}_{2} \mathrm{Ga}_{9}$ & $0.058 \mathrm{~g} \mathrm{Rh} ; 0.938 \mathrm{~g} \mathrm{Ga}\left(\mathrm{Rh}_{0.040} \mathrm{Ga}_{0.960}\right)$ & 5 days at $500{ }^{\circ} \mathrm{C}$ \\
\hline $\mathrm{Ir}_{2} \mathrm{Ga}_{9}$ & $0.079 \mathrm{~g} \mathrm{Ir} ; 0.921 \mathrm{~g} \mathrm{Ga}\left(\mathrm{Ir}_{0.030} \mathrm{Ga}_{0.970}\right)$ & $\begin{array}{l}12 \mathrm{~h} \text { at } 500{ }^{\circ} \mathrm{C} \\
+ \text { cooling down to } \\
100^{\circ} \mathrm{C} \text { by } 2^{\circ} \mathrm{C} / \mathrm{h}\end{array}$ \\
\hline
\end{tabular}

manufactured from tantalum plate with five holes of $0.5 \mathrm{~mm}$ diameter. These containers were subsequently sealed inside evacuated quartz tubes. Heat treatment conditions are listed in Table 1. The melt was removed by high temperature centrifugation-aided filtration (HT-CAF, [5]) at elevated temperature immediately after the heat treatment. The solid phase remaining after the separation was found to be single crystals of the respective $\mathrm{T}_{2} \mathrm{Al}_{9}$ phase. Preparation of the gallides $\mathrm{T}_{2} \mathrm{Ga}_{9}(\mathrm{~T}=\mathrm{Rh}$, Ir) was performed analogously, but in quartz ampoules with quartz wool filters instead of tantalum containers.

Metallographic analysis on $\mathrm{Ir}_{2} \mathrm{Ga}_{9}$ was performed on resin mounted samples polished by the use of $1 \mu \mathrm{m}$ polycrystalline diamond powder followed by $0.25 \mu \mathrm{m}$ alumina finishing. Bright-field contrast as well as polarization contrast procedures in an optical microscope were used to investigate the homogeneity of the microstructure as well as grain or domain orientations. Image filters were applied to the CCD images of the microstructures for contrast enhancement. 
Table 2 Data collection and handling

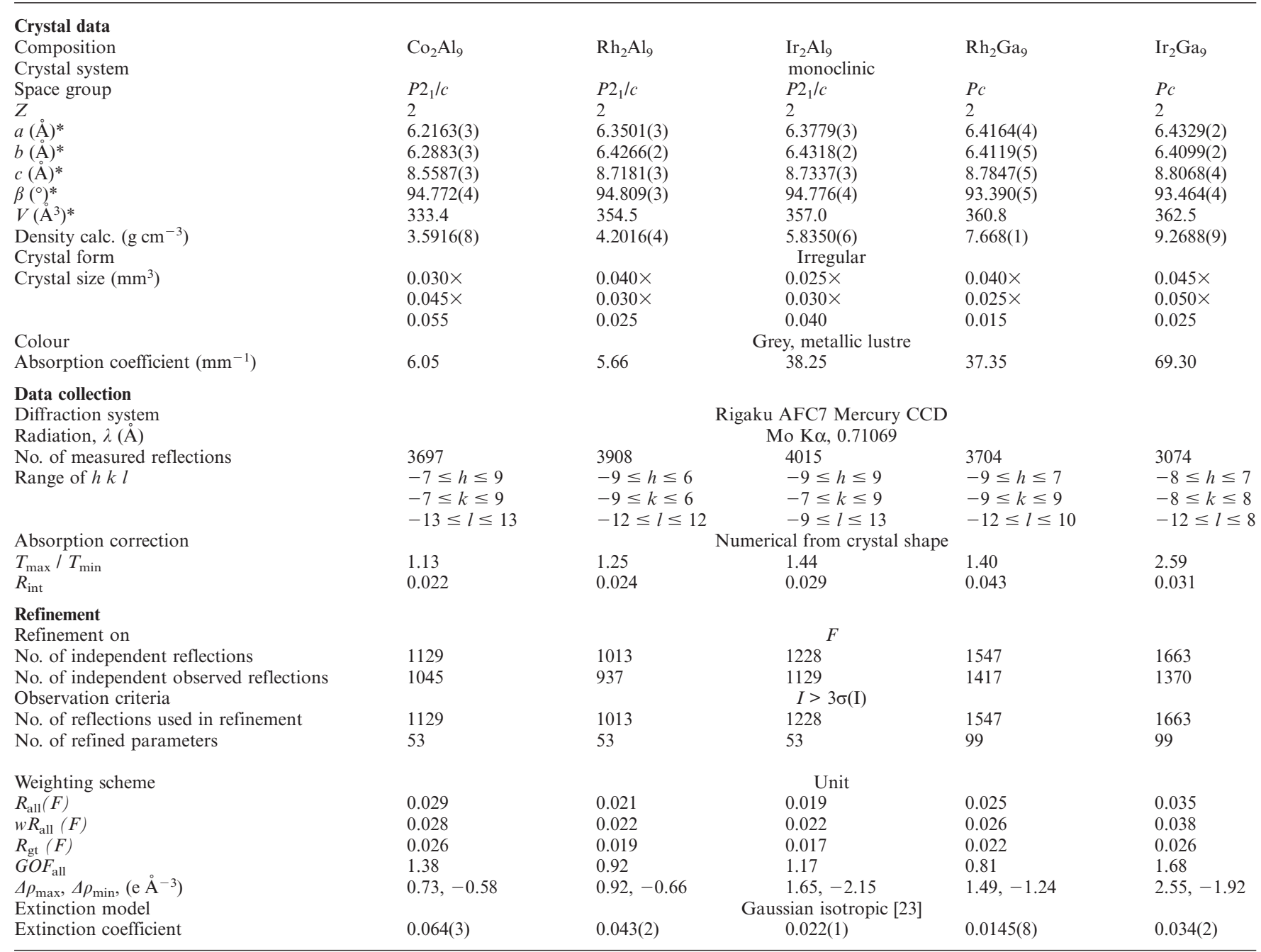

* Refined from Guinier powder diffraction data with internal standard.

X-ray powder diffraction patterns of the powdered single crystals were collected with a Huber Imaging Plate Guinier Camera G670 using $\mathrm{Cu} K \alpha_{1}$ radiation $(\lambda=1.54060 \AA)$ for all samples except that containing $\mathrm{Co}_{2} \mathrm{Al}_{9}$, for which $\mathrm{Co} K \alpha_{1}(\lambda=1.78897 \AA)$ radiation was used. Silicon powder $(a=5.43119(1) \AA)$ was added as internal standard for all samples except that of $\mathrm{Co}_{2} \mathrm{Al}_{9}$, for which $\mathrm{LaB}_{6}(a=$ 4.15692(1) §) was used. The lattice parameters were refined from the powder data using the CELREF program [6].

Suitable single crystals for the X-ray diffraction experiment were cleaved with a scalpel under ethanol from the larger ones and then mounted on a thin glass capillary using two component epoxy glue. The data were collected on a Rigaku AFC7 diffraction system

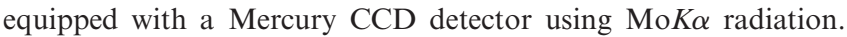
Numerical absorption corrections were performed using the CrystalClear program package [7]. The crystal structures were refined with the JANA2000 program [8]. The refined parameters were, for each structure, the scale factor, atomic coordinates, anisotropic displacement parameters and extinction coefficient. The volume fraction of the inversion twins was refined to determine the absolute structure of the gallides. See Table 2 for details about the data collection and handling.
The TB-LMTO-ASA program package [9] with exchange correlation potential according to Barth and Hedin [10] was used for quantum chemical calculations (LDA). The radial scalar-relativistic Dirac equation was solved to get the partial waves. The calculation within the atomic sphere approximation (ASA) includes corrections for the neglect of interstitial regions and partial waves of higher order [11], hence an addition of empty spheres in the cases of $\mathrm{Rh}_{2} \mathrm{Ga}_{9}$ and $\mathrm{Rh}_{2} \mathrm{Al}_{9}$ was not necessary. The following radii of atomic spheres were applied for the calculations on $\mathrm{Rh}_{2} \mathrm{Ga}_{9}$ : $r(\mathrm{Rh})=1.537,1.542 \AA ; r(\mathrm{Ga})=1.574,1.572,1.682,1.661,1.534$, $1.577,1.596,1.404,1.472 \AA$; on $\mathrm{Rh}_{2} \mathrm{Al}_{9}: r(\mathrm{Rh})=1.524 \AA ; r(\mathrm{Al})=$ $1.558,1.639,1.568,1.586,1.470 \AA$ (see Table 3 for labelling of the atoms). Basis sets containing $\mathrm{Rh}(5 s, 5 p, 4 d), \mathrm{Al}(3 s, 3 p)$ or $\mathrm{Ga}(4 s, 4 p)$ orbitals were employed for the self-consistent calculations with the $\mathrm{Rh}(4 f), \mathrm{Ga}(4 d)$ and $\mathrm{Al}(3 d)$ functions being downfolded.

The electron localization function (ELF) was evaluated according to [12] with an ELF module already implemented within the TB-LMTO-ASA program package [9]. To gain a deeper insight into the chemical bonding, the topology of ELF was analysed with the program Basin [13]. The electron density was integrated in basins, which were bounded by zero-flux surfaces in the ELF gradient. 
Table 3 Atomic coordinates and displacement parameters (in $\left.\AA^{2}\right)$ for the compounds with the $\mathrm{Co}_{2} \mathrm{Al}_{9}$ and $\mathrm{Rh}_{2} \mathrm{Ga}_{9}$ structure types $(\mathrm{T}-$ transition metal)

\begin{tabular}{|c|c|c|c|c|c|c|}
\hline & & $\mathrm{Co}_{2} \mathrm{Al}_{9}$ & $\mathrm{Rh}_{2} \mathrm{Al}_{9}$ & $\mathrm{Ir}_{2} \mathrm{Al}_{9}$ & $\mathrm{Rh}_{2} \mathrm{Ga}_{9}$ & $\mathrm{Ir}_{2} \mathrm{Ga}_{9}$ \\
\hline T1a & $\begin{array}{l}x^{*} \\
y \\
z^{*} \\
U_{e q}{ }^{* *}\end{array}$ & $\begin{array}{l}0.73683(5) \\
0.11844(5) \\
0.16693(4) \\
0.00630(9)\end{array}$ & $\begin{array}{l}0.73661(4) \\
0.12193(4) \\
0.16845(3) \\
0.00537(7)\end{array}$ & $\begin{array}{l}0.73673(3) \\
0.12194(3) \\
0.16833(2) \\
0.00409(6)\end{array}$ & $\begin{array}{l}0.7401 \\
0.8783(2) \\
0.1685 \\
0.0062(2)\end{array}$ & $\begin{array}{l}0.7393 \\
0.8752(1) \\
0.1683 \\
0.0059(3)\end{array}$ \\
\hline $\mathrm{T} 1 \mathrm{~b}$ & $\begin{array}{l}x \\
y \\
z \\
U_{e q}\end{array}$ & - & - & - & $\begin{array}{l}-0.7398(2) \\
0.6239(2) \\
-0.16903(9) \\
0.0066(2)\end{array}$ & $\begin{array}{l}-0.7400(1) \\
0.6224(1) \\
-0.16833(9) \\
0.0051(3)\end{array}$ \\
\hline Gala / Alla & $\begin{array}{l}x \\
y \\
z \\
U_{e q}\end{array}$ & $\begin{array}{l}0.5940(2) \\
0.4664(2) \\
0.23200(9) \\
0.0103(2)\end{array}$ & $\begin{array}{l}0.5982(2) \\
0.4766(2) \\
0.2304(2) \\
0.0100(2)\end{array}$ & $\begin{array}{l}0.5988(2) \\
0.4781(3) \\
0.2299(2) \\
0.0087(4)\end{array}$ & $\begin{array}{l}0.5986(3) \\
0.2369(2) \\
0.2307(2) \\
0.0125(4)\end{array}$ & $\begin{array}{l}0.5997(6) \\
0.2379(5) \\
0.2264(5) \\
0.0109(9)\end{array}$ \\
\hline Galb & $\begin{array}{l}x \\
y \\
z \\
U_{e q}\end{array}$ & - & - & - & $\begin{array}{l}-0.5993(3) \\
0.2623(2) \\
-0.2260(2) \\
0.0127(4)\end{array}$ & $\begin{array}{l}-0.6004(6) \\
0.2635(5) \\
-0.2325(5) \\
0.0111(9)\end{array}$ \\
\hline $\mathrm{Ga} 2 \mathrm{a} / \mathrm{A} 12 \mathrm{a}$ & $\begin{array}{l}x \\
y \\
z \\
U_{e q}\end{array}$ & $\begin{array}{l}0.6101(2) \\
0.6913(2) \\
0.50228(9) \\
0.0095(2)\end{array}$ & $\begin{array}{l}0.6113(2) \\
0.6946(2) \\
0.5024(2) \\
0.0093(2)\end{array}$ & $\begin{array}{l}0.6113(2) \\
0.6931(3) \\
0.5007(2) \\
0.0081(4)\end{array}$ & $\begin{array}{l}0.5997(3) \\
0.4453(2) \\
0.5084(2) \\
0.0139(4)\end{array}$ & $\begin{array}{l}0.6130(6) \\
0.4456(5) \\
0.4999(5) \\
0.0113(9)\end{array}$ \\
\hline $\mathrm{Ga} 2 \mathrm{~b}$ & $\begin{array}{l}x \\
y \\
z \\
U_{\text {eq }}\end{array}$ & - & - & - & $\begin{array}{l}-0.6141(3) \\
0.0557(2) \\
-0.5023(2) \\
0.0123(4)\end{array}$ & $\begin{array}{l}-0.6018(6) \\
0.0545(5) \\
-0.5076(5) \\
0.0127(9)\end{array}$ \\
\hline $\mathrm{Ga3a} / \mathrm{Al} 3 \mathrm{a}$ & $\begin{array}{l}x \\
y \\
z \\
U_{e q}\end{array}$ & $\begin{array}{l}0.9123(2) \\
0.7897(2) \\
0.27056(9) \\
0.0106(2)\end{array}$ & $\begin{array}{l}0.9048(2) \\
0.7869(2) \\
0.2722(2) \\
0.0104(2)\end{array}$ & $\begin{array}{l}0.9033(2) \\
0.7850(3) \\
0.2721(2) \\
0.0093(4)\end{array}$ & $\begin{array}{l}0.9109(3) \\
0.5491(2) \\
0.2678(2) \\
0.0162(4)\end{array}$ & $\begin{array}{l}0.8929(6) \\
0.5285(5) \\
0.2791(5) \\
0.0121(8)\end{array}$ \\
\hline $\mathrm{Ga} 3 \mathrm{~b}$ & $\begin{array}{l}x \\
y \\
z \\
U_{e q}\end{array}$ & - & - & - & $\begin{array}{l}-0.8958(3) \\
0.9691(2) \\
-0.2828(2) \\
0.0137(4)\end{array}$ & $\begin{array}{l}-0.9091(6) \\
0.9566(5) \\
-0.2687(5) \\
0.0145(9)\end{array}$ \\
\hline $\mathrm{Ga} 4 \mathrm{a} / \mathrm{Al} 4 \mathrm{a}$ & $\begin{array}{l}x \\
y \\
z \\
U_{e q}\end{array}$ & $\begin{array}{l}0.7837(2) \\
0.1143(2) \\
0.45675(9) \\
0.0096(2)\end{array}$ & $\begin{array}{l}0.7869(2) \\
0.1077(2) \\
0.4604(2) \\
0.0098(2)\end{array}$ & $\begin{array}{l}0.7859(2) \\
0.1055(3) \\
0.4609(2) \\
0.0086(4)\end{array}$ & $\begin{array}{l}0.7816(3) \\
0.8461(3) \\
0.4614(2) \\
0.0165(4)\end{array}$ & $\begin{array}{l}0.7979(6) \\
0.8616(5) \\
0.4568(5) \\
0.014(1)\end{array}$ \\
\hline $\mathrm{Ga} 4 \mathrm{~b}$ & $\begin{array}{l}x \\
y \\
z \\
U_{e q}\end{array}$ & - & - & - & $\begin{array}{l}-0.7998(3) \\
0.6343(2) \\
-0.4570(2) \\
0.0156(4)\end{array}$ & $\begin{array}{l}-0.7842(6) \\
0.6573(6) \\
-0.4622(5) \\
0.016(1)\end{array}$ \\
\hline $\mathrm{Ga} 5 / \mathrm{A} 15$ & $\begin{array}{l}x \\
y \\
z \\
U_{e q}\end{array}$ & $\begin{array}{l}0 \\
0 \\
0 \\
0.0119(3)\end{array}$ & $\begin{array}{l}0 \\
0 \\
0 \\
0.0157(4)\end{array}$ & $\begin{array}{l}0 \\
0 \\
0 \\
0.0162(7)\end{array}$ & $\begin{array}{l}-0.0320(3) \\
0.7611(3) \\
-0.0302(2) \\
0.0296(6)\end{array}$ & $\begin{array}{l}0.0299(6) \\
0.7415(6) \\
0.0272(5) \\
0.027(1)\end{array}$ \\
\hline
\end{tabular}

* Fixed during refinement of the gallides.

** $U_{e q}=\frac{1}{3} \sum_{i} \sum_{j} U_{i j} a_{i}^{*} a_{j}^{*} a_{i} a_{j}$

This method is analogous to the procedure proposed by Bader for electron density analysis [14] and provides electron counts for each basin. The electron counts reveal basic information for the description of the bonding situation $[15,16]$.

A full-potential non-orthogonal local-orbital calculation scheme (FPLO, [17]) was applied, within the L(S)DA, in order to obtain more accurate values of the total energy for different symmetry (space groups $P c$ and $P 2_{1} / c$ ) and detailed electronic structure information (e.g. electronic DOS). No optimisation of the atomic parameters was performed and the experimentally determined values were used for all calculations. In the scalar-relativistic calculations, the exchange and correlation potential of Pedrew and Wang [18] was used. The basis sets of $\operatorname{Rh}(4 s, 4 p, 5 s, 5 p, 4 d), \operatorname{Ir}(5 s, 5 p, 6 s, 6 p, 5 d)$, $\mathrm{Al}(2 s, 2 p, 3 s, 3 p, 3 d)$ and $\mathrm{Ga}(3 s, 3 p, 4 s, 4 p, 4 d)$ states were employed and the lower lying sets were treated fully relativistically as core states. The inclusion of the $\mathrm{Rh}(4 s, 4 p), \operatorname{Ir}(5 s, 5 p), \mathrm{Ga}(3 s, 3 p)$ and $\mathrm{Al}(2 s, 2 p)$ states into the valence range was necessary to account for the nonnegligible overlap of these states. The spatial extension of the basic orbitals, controlled by a confining potential $\left(r / r_{0}\right)^{4}$, was optimised to minimise the total energy [19]. A $k$-mesh of 396 points in the irreducible part of the Brillouin zone was used to ensure accurate density of states information. To be able to compare the total energy values for different structures, the calculations were performed in the space group $P c$. To account for the symmetry of the space group $P 2_{1} / c$, the additional elements of symmetry were introduced by the use of the atomic coordinates strictly obeying these symmetry elements. Both possible absolute structures in the space group $P c$ were calculated to prove the quality of the numerical calculations, resulting in identical values of the total energy $\left(\Delta E_{\text {tot }}\right.$ $<10^{-8}$ Hartree).

\section{Results and discussion}

Metallographic investigations of the single crystals of $\mathrm{Ir}_{2} \mathrm{Ga}_{9}$ did not reveal any signs of macroscopic twinning. None of the crystals showed any signs of containing more than one grain (Fig. 1).

We note that the monoclinic angle of the unit cells of $\mathrm{Rh}_{2} \mathrm{Ga}_{9}$ and $\mathrm{Ir}_{2} \mathrm{Ga}_{9}$ refined in the present study (see Table 


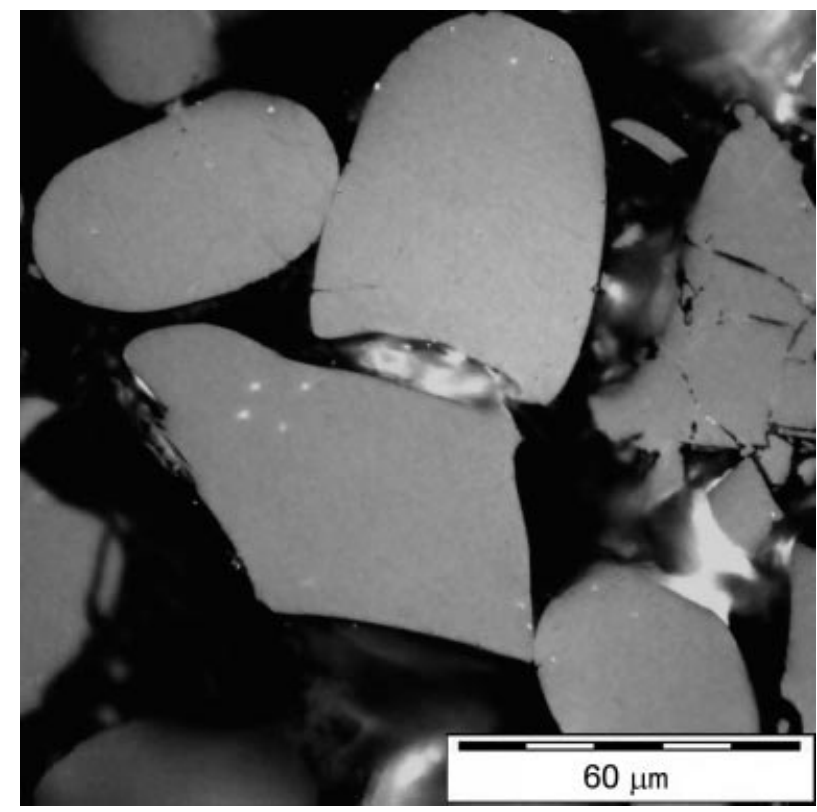

Fig. 1 Homogeneous microstructure of $\mathrm{Ir}_{2} \mathrm{Ga}_{9}$ crystals (grey) mounted in phenolic resin (dark) [objective $20 \times$, polarized light, contrast-enhanced CCD image].

2) differs more than $3^{\circ}$ from those in [3]. The other cell parameters differ less than $0.05 \AA$.

The crystal structures of $\mathrm{Rh}_{2} \mathrm{Ga}_{9}$ and $\mathrm{Ir}_{2} \mathrm{Ga}_{9}$ were first refined in the space group $P 2_{1} / c$, using the published atomic parameters of $\mathrm{Co}_{2} \mathrm{Al}_{9}$ as starting model. Most of the $\mathrm{Ga}$ atoms showed stronger anisotropy in atomic displacement in comparison with the corresponding $\mathrm{Al}$ atom in $\mathrm{T}_{2} \mathrm{Al}_{9}$. Especially pronounced anisotropic displacement was observed for Ga5, positioned at the inversion center (Fig. 2). Additionally, a detailed analysis of the single crystal diffraction data revealed that the 050 and $0 \overline{5} 0$ reflections, which should be systematically absent in the space group $P 2_{1} / c$ due to the two-fold screw axis, were clearly observed in the recorded diffraction patterns of both gallides $(I / \sigma(I)=$ 18.5 for $\mathrm{Rh}_{2} \mathrm{Ga}_{9}$ and $I / \sigma(I)=5.7$ for $\mathrm{Ir}_{2} \mathrm{Ga}_{9}$ ). The difference is hard to recognise in powder diffraction data, as the reflections in question are overlapped by other strong reflections. The observation of these reflections that should be systematically extinct in the space group $P 2_{1} / c$ leads to another extinction class with the two possible space groups $P 2 / c$ and $P c$. For structural reasons, the centrosymmetric space group $P 2 / c$ is irrelevant, since this space group is not appropriate for the description of the packing of the polar polyhedra in the $\mathrm{Co}_{2} \mathrm{Al}_{9}$ structure type. Thus the space group $P c$ was choosen, whereby all residual values decreased significantly $\left(R_{\mathrm{gt}}(F)\right.$ from 0.062 to 0.021 for $\mathrm{Rh}_{2} \mathrm{Ga}_{9}$ and from 0.037 to 0.024 for $\mathrm{Ir}_{2} \mathrm{Ga}_{9}$ ). The $x$ and $z$ coordinates for Ir1a and Rhla were fixed to the coordinates of the corresponding atom obtained in the refinement in the space group $P 2_{1} / c$ in order to define the origin. The $y$ coordinates in the $\mathrm{T}_{2} \mathrm{Ga}_{9}$ structures differ from those in $\mathrm{T}_{2} \mathrm{Al}_{9}$ by 0.25 , due to the different location of the glide mirror plane perpendicular to [010] in the space groups $P 2_{1} / c$ and $P c$.

The volume fraction of the inversion twin was refined in order to obtain the absolute structure, a method that can be used as analogous to the Flack parameter [20]. In the case of $\mathrm{Rh}_{2} \mathrm{Ga}_{9}$, the volume fraction of the inversion twin was found to be $0.03(3)$, which indicated that the absolute structure of the investigated crystal of $\mathrm{Rh}_{2} \mathrm{Ga}_{9}$ was correctly described. In the case of $\operatorname{Ir}_{2} \mathrm{Ga}_{9}$, the fraction of the inversion twin was refined to be $0.57(4)$, but without a decisive decrease in residuals (from $R_{\mathrm{gt}}(F)=0.026$ to $R_{\mathrm{gt}}(F)=$ $0.024)$. Additionally, the difference in residuals between the possible absolute structures was extremely small $(0.003$ in $R_{\mathrm{gt}}(F)$ ). Together with the results of optical metallography, this suggest that the $\mathrm{Ir}_{2} \mathrm{Ga}_{9}$ crystal is not twinned. Establishing of the absolute structure is in this case not trivial, due to the nearly double as strong relative contribution of Ir compared with $\mathrm{Rh}$ to the diffraction intensities in combination with the practically centrosymmetric transition metal positions in $\mathrm{Ir}_{2} \mathrm{Ga}_{9}$ compared with $\mathrm{Rh}_{2} \mathrm{Ga}_{9}$. The second possibility that was considered is that the crystals of $\mathrm{Ir}_{2} \mathrm{Ga}_{9}$ are roughly racematically twinned at a scale not observable with a light-optical microscope. However, the fact that the chemically very similar compound $\mathrm{Rh}_{2} \mathrm{Ga}_{9}$ did not show any sign of twinning from the diffraction data, strongly suggests the absence of twinning also in $\mathrm{Ir}_{2} \mathrm{Ga}_{9}$.

Refinement of the crystal structures of $\mathrm{Rh}_{2} \mathrm{Ga}_{9}$ and $\mathrm{Ir}_{2} \mathrm{Ga}_{9}$ in the space group $P c$ markedly reduced the aniso-

Table 4 Interatomic distances (in $\AA$ ) for $\mathrm{T}_{2} \mathrm{Al}_{9}$ and $\mathrm{T}_{2} \mathrm{Ga}_{9}$ compounds $(\mathrm{T}=\mathrm{Co}, \mathrm{Rh}, \mathrm{Ir})$.

\begin{tabular}{|c|c|c|c|c|c|c|c|}
\hline Distances & $\mathrm{Co}_{2} \mathrm{Al}_{9}$ & $\mathrm{Rh}_{2} \mathrm{Al}_{9}$ & $\mathrm{Ir}_{2} \mathrm{Al}_{9}$ & $\begin{array}{l}\mathrm{Rh}_{2} \mathrm{Ga}_{9} \\
\text { in } \mathrm{Pc}\end{array}$ & $\begin{array}{l}\mathrm{Ir}_{2} \mathrm{Ga}_{9} \\
\text { in Pc }\end{array}$ & $\begin{array}{l}\mathrm{Rh}_{2} \mathrm{Ga}_{9} \\
\text { in } \mathrm{P} 2_{1} / \mathrm{c}\end{array}$ & $\begin{array}{l}\mathrm{Ir}_{2} \mathrm{Ga}_{9} \\
\text { in } \mathrm{P} 2_{1} / \mathrm{c}\end{array}$ \\
\hline $\begin{array}{l}\mathrm{T}-(\mathrm{Al}, \mathrm{Ga})^{\mathrm{a})} \\
\mathrm{T}-(\mathrm{Al} 5, \mathrm{Ga} 5)\end{array}$ & $\begin{array}{l}2.443-2.538 \\
2.379\end{array}$ & $\begin{array}{l}2.517-2.601 \\
2.445\end{array}$ & $\begin{array}{l}2.527-2.601 \\
2.451\end{array}$ & $\begin{array}{l}2.507-2.690 \\
2.457-2.463\end{array}$ & $\begin{array}{l}2.537-2.672 \\
2.459-2.461\end{array}$ & $\begin{array}{l}2.545-2.633 \\
2.437\end{array}$ & $\begin{array}{l}2.549-2.655 \\
2.441\end{array}$ \\
\hline $\left.1-\frac{\mathrm{T}-(\mathrm{Al} 15, \mathrm{Ga} 5)}{\mathrm{T}-(\mathrm{Al}, \mathrm{Ga})} \times 100 \% \mathrm{~b}\right)$ & 2.6 & 2.9 & 3.0 & $1.8-2.0$ & $3.1-3.2$ & 4.2 & 4.2 \\
\hline $\begin{array}{l}\mathrm{Al}-\mathrm{Al}, \mathrm{Ga}-\mathrm{Ga}^{\mathrm{c})} \\
\mathrm{Al} 5-\mathrm{Al}, \mathrm{Ga} 5-\mathrm{Ga}^{\mathrm{d})}\end{array}$ & $\begin{array}{l}2.706-2.941 \\
2.701-2.783\end{array}$ & $\begin{array}{l}2.750-2.993 \\
2.740-2.868\end{array}$ & $\begin{array}{l}2.735-2.964 \\
2.738-2.888\end{array}$ & $\begin{array}{l}2.699-2.971 \\
2.681-2.990\end{array}$ & $\begin{array}{l}2.671-2.987 \\
2.654-2.996\end{array}$ & $\begin{array}{l}2.712-2.992 \\
2.755-2.875\end{array}$ & $\begin{array}{l}2.719-2.954 \\
2.750-2.895\end{array}$ \\
\hline
\end{tabular}

a) All $\mathrm{T}-(\mathrm{Al}, \mathrm{Ga})$ distances except $\mathrm{T}-(\mathrm{A} 15, \mathrm{Ga} 5)$

b) Relative difference between the shortest heteroatomic distance $(\mathrm{T}-(\mathrm{A} 15, \mathrm{Ga} 5))$ and the next shortest heteroatomic distance in the structure.

c) $\mathrm{All} \mathrm{Al}-\mathrm{Al}$ or $\mathrm{Ga}-\mathrm{Ga}$ distances except those including $\mathrm{A} 15$ or $\mathrm{Ga} 5$.

d) Homoatomic distances involving A15 or Ga5. 

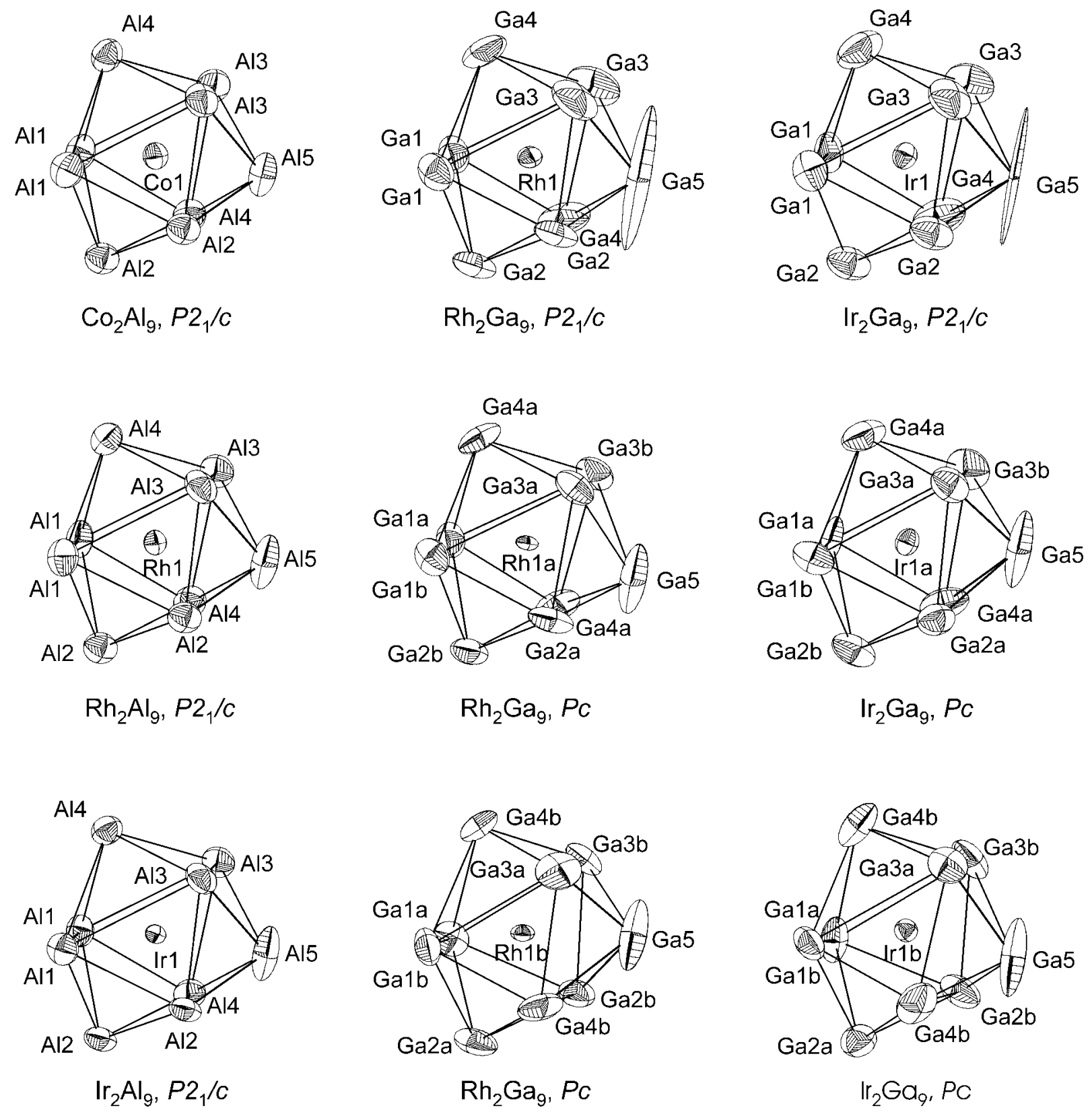

Fig. 2 Coordination polyhedra around the transition metals with atomic displacement ellipsoids ( $99.5 \%$ probability) in the crystal structures of $\mathrm{T}_{2} \mathrm{Al}_{9}$ and $\mathrm{T}_{2} \mathrm{Ga}_{9}(\mathrm{~T}=\mathrm{Co}, \mathrm{Rh}, \mathrm{Ir})$. For the gallides, models obtained both in the space group $P 2_{1} / c$ and in the space group $P c$ are shown.

tropy of the displacement of the $\mathrm{Ga}$ atoms in comparison with the refinement in space group $P 2_{1} / c$ (Fig. 2). The displacement ellipsoids approached the size of those of $\mathrm{Al}$ in the aluminides $\mathrm{T}_{2} \mathrm{Al}_{9}$. Final values of atomic coordinates and displacement parameters for the gallides $\mathrm{T}_{2} \mathrm{Ga}_{9}$ are presented in Table 3. Since the determination of the absolute structure of $\operatorname{Ir}_{2} \mathrm{Ga}_{9}$ failed, Table 3 contains the crystallographic parameters for the absolute structure analogous to $\mathrm{Rh}_{2} \mathrm{Ga}_{9}$ for facilitating comparison.

None of the aluminides showed any sign of deviation from the symmetry of the space group $P 2_{1} / c$, and the 050 and $0 \overline{5} 0$ reflections were absent in the single crystal diffraction data sets. Final atomic coordinates and displacement parameters for the aluminides are shown in Table 3. Relevant interatomic distances are listed in Table 4.

The $\mathrm{Co}_{2} \mathrm{Al}_{9}$ structure type can be described in terms of single-capped square antiprismatic coordination polyhedra around the transition metal atoms (Fig. 3, top). These polyhedra build up zig-zag strands parallel to the $c$ axis. The strands are arranged in a simple quadratic rod packing (see Fig. 3, bottom). It should be noted that a single-capped square antiprism can also be described as a trigonal prism with capped rectangular faces, a view used in Fig. 2. However, the single capped square antiprism lends itself better for the use in the structural description in Fig. 3. Another advantage is that it better reflects the relation of the $\mathrm{Co}_{2} \mathrm{Al}_{9}$ 

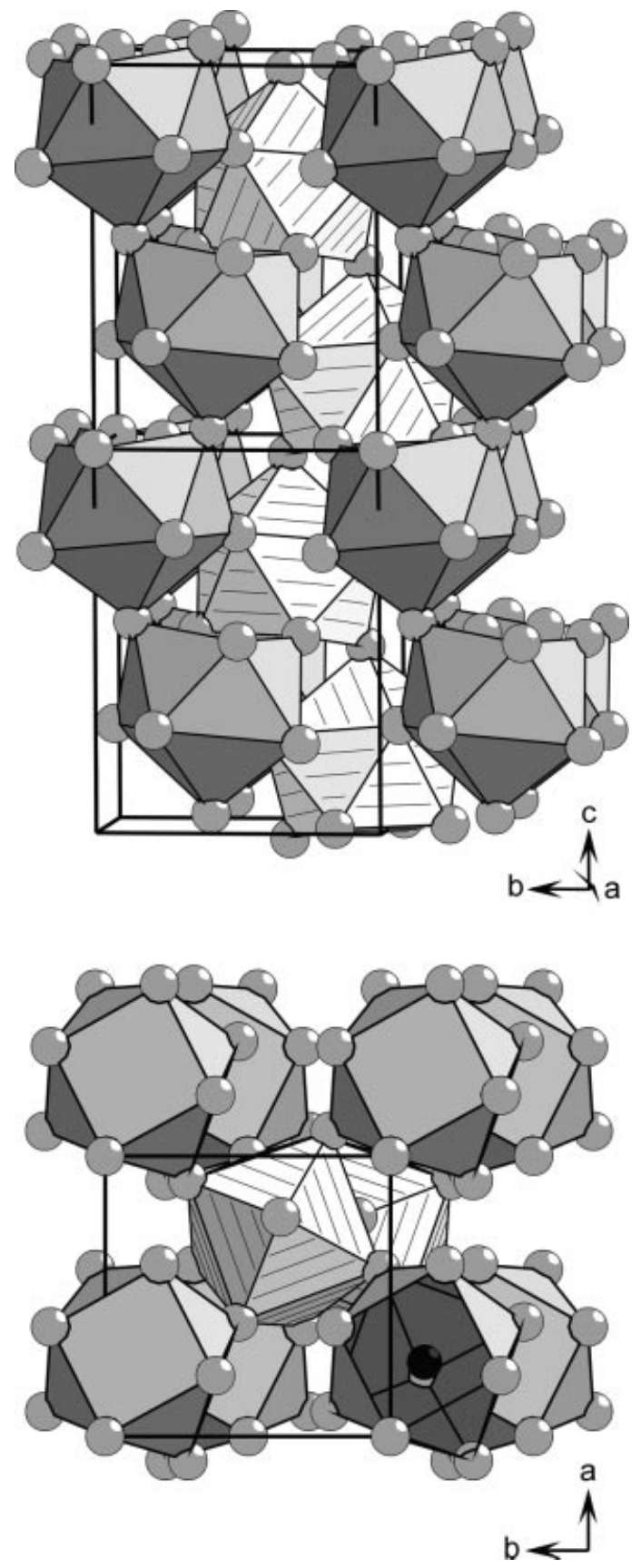

Fig. 3 Views along [100] (top) and [001] (bottom) of the $\mathrm{Co}_{2} \mathrm{Al}_{9}$ structure. Monocapped square antiprisms $\left[\mathrm{CoAl}_{9}\right]$ with different orientations relative to [001] are drawn light grey hatched and grey, respectively. The antiprism down to the right is drawn with one face open, exposing the centering Ir atom.

and $\mathrm{Rh}_{2} \mathrm{Ga}_{9}$ structures to the parent structure of $\mathrm{CuAl}_{2}$, where the tetragonal symmetry of the polyhedron is clearly exhibited.

The structure of $\mathrm{Rh}_{2} \mathrm{Ga}_{9}$ represents a new structure type due to the different space group caused by the slight distortion of the $\mathrm{Co}_{2} \mathrm{Al}_{9}$ archetype structure. In the low-symmetry gallides, each of the zig-zag strands contains polyhedra of only one of the two crystallographically indepen-
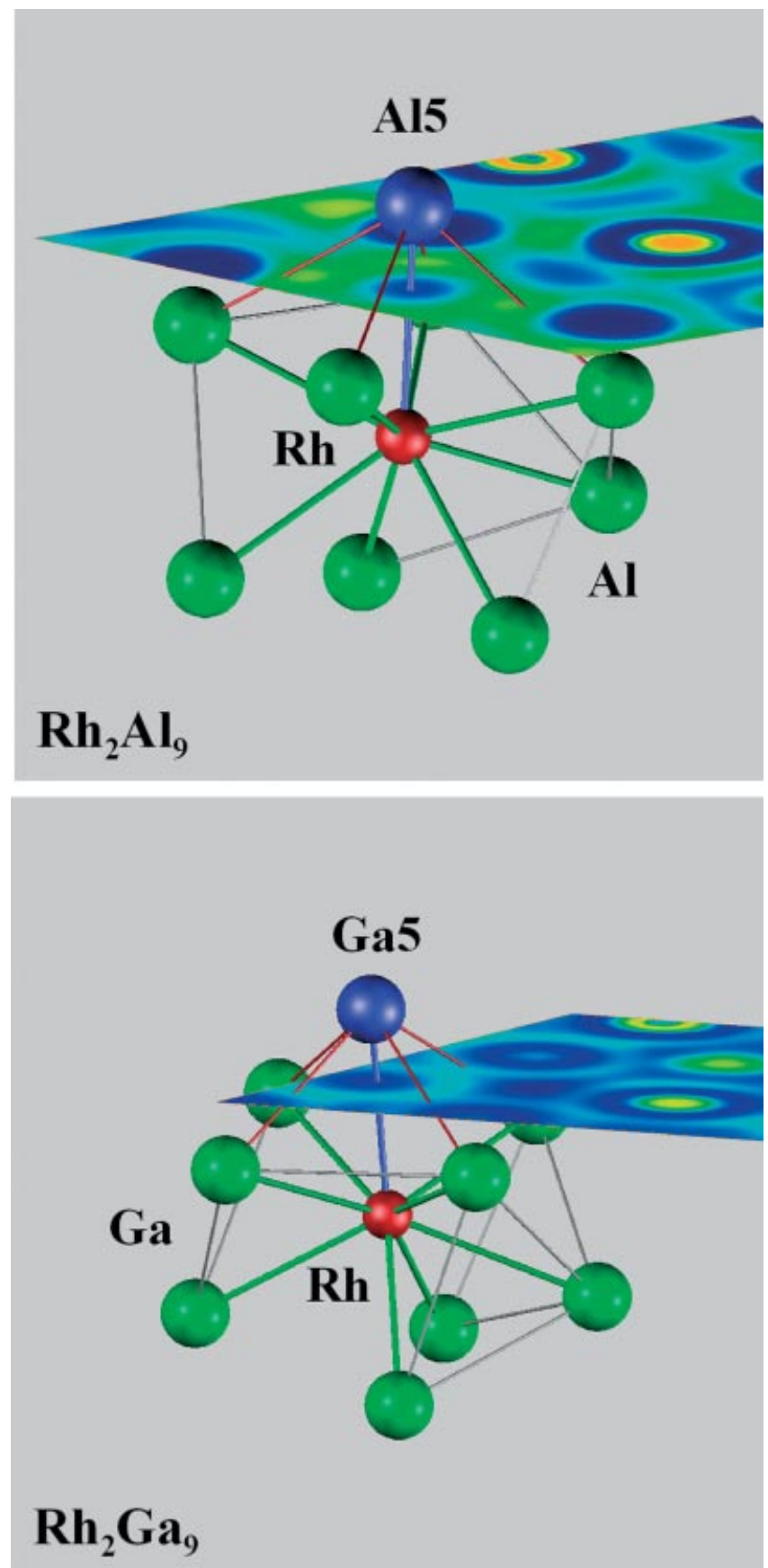

Fig. 4 Electron localization function for $\mathrm{Rh}_{2} \mathrm{Al}_{9}$ (top) and $\mathrm{Rh}_{2} \mathrm{Ga}_{9}$ (bottom) in the vicinity of the $\mathrm{Rh}-\mathrm{Al} 5$ and $\mathrm{Rh}-\mathrm{Ga} 5$ bonds (blue sticks). In the two-dimensional sections of ELF nearly normal to the $\mathrm{T}-(\mathrm{A} 15, \mathrm{Ga} 5)$ bonds, the high values of ELF are represented by bright orange for $\mathrm{Rh}_{2} \mathrm{Al}_{9}$ and greenish blue for $\mathrm{Rh}_{2} \mathrm{Ga}_{9}$.

dent transition metal atoms. The atom Ga5, which is located at the inversion center in the $\mathrm{Co}_{2} \mathrm{Al}_{9}$ archetype, is the strongest contributor to the observed symmetry breaking in the gallides, with a shift of $0.32 \AA$ along the [101] direction in $\mathrm{Ir}_{2} \mathrm{Ga}_{9}$. All other atoms shift less than $0.12 \AA$ with average displacement of $0.06 \AA$.

The $\mathrm{T}-(\mathrm{A} 15, \mathrm{Ga} 5)$ distances are in all the structures $1.8-$ $3.2 \%$ shorter than the rest of the $\mathrm{T}-(\mathrm{Al}, \mathrm{Ga})$ distances 
within the structures (Table 4). When the gallides were refined with the symmetry constraints of the space group $P 2_{1} / c$, i.e. $\mathrm{Ga} 5$ is placed at an inversion center, the resulting difference was $4.2 \%$ in both gallide structures. The symmetry reduction evidently offers a route to relieve the geometric strain in the gallides. The geometric strain that exists mainly around A15 in the aluminides does not seem to be enough to cause a reduction of the symmetry. However, one may note that the atomic displacement of A15 in the aluminides are the largest among all atoms in those structures. The unit cell volumes for the aluminides $\mathrm{T}_{2} \mathrm{Al}_{9}$ and the gallides $\mathrm{T}_{2} \mathrm{Ga}_{9}$ differ only by $1-2 \%$. Hence, the size effect may not be enough to cause the symmetry reduction. We suggest that the origin of this effect has to be found in the special features of the bonding interactions.

The electron localization function reveals that two-center covalent $\mathrm{Al}-\mathrm{Al}$ and $\mathrm{Ga}-\mathrm{Ga}$ interactions, especially between the antiprisms, play a key role in the stabilisation of the different structures of $\mathrm{Rh}_{2} \mathrm{Al}_{9}$ and $\mathrm{Rh}_{2} \mathrm{Ga}_{9}$. This is in good agreement with the results of the bonding analysis in $\mathrm{PdGa}_{5}$ [21] and $\mathrm{CuAl}_{2}$ [22] where the covalent interactions were found primarly between $\mathrm{Ga}(\mathrm{Al})$ atoms belonging to neighbouring tetragonal antiprisms. The difference between the two structures can be observed within the vicinity of the $\mathrm{Rh}-\mathrm{Al} 5$ and $\mathrm{Rh}-\mathrm{Ga} 5$ bonds inside the antiprisms (Fig. 4). For $\mathrm{Rh}_{2} \mathrm{Al}_{9}$, the ELF attractors are located at the $\mathrm{Al} 5-\mathrm{Al}$ bonds (red in Fig. 4). In $\mathrm{Rh}_{2} \mathrm{Ga}_{9}$ the attractors are shifted from the $\mathrm{Ga} 5-\mathrm{Ga}$ bonds toward the $\mathrm{Rh}-\mathrm{Ga} 5$ contact, forming a ring attractor set similar to the $\mathrm{Sc}-\mathrm{Ga}$ bonds observed in [16] for $\mathrm{ScGa}$ molecule. This suggests a more directional $\mathrm{Rh}-\mathrm{Ga} 5$ interaction in comparison with $\mathrm{Rh}-\mathrm{Al}$, which inhibits the achievement of higher symmetry in the the two gallides $\mathrm{T}_{2} \mathrm{Ga}_{9}$.

This behaviour is also confirmed by the band structure calculations for $\mathrm{Ir}_{2} \mathrm{Al}_{9}$ and $\mathrm{Ir}_{2} \mathrm{Ga}_{9}$. The electronic density of states (DOS) of $\operatorname{Ir}_{2} \mathrm{Al}_{9}$ (Fig. 5, top) shows a similar picture for both space groups with a relatively low density of states at the Fermi level. The overlap of the $\mathrm{Ir}-4 d$ and $\mathrm{Al}-3(s+p)$ contributions in the valence region suggests bonding interaction between Ir and Al, (cf. ELF analysis). A pronounced difference between the structures with different symmetry is observed only in the middle of this region $(-5 \mathrm{eV} \leq E \leq$ $-3 \mathrm{eV}$ ). This leads to the conclusion that the difference between the structure variants crystallising in the space groups $P c$ and $P 2_{1} / c$ respectively is caused mainly by the difference in the interactions between Ir and Al compared with the interactions between Ir and Ga. This is in good agreement with the ELF analysis. Indeed, for $\operatorname{Ir}_{2} \mathrm{Al}_{9}$ the variant with the symmetry $P 2_{1} / c$ has a total energy lower by $80 \mathrm{meV}$ in comparison with the $P c$ variant. This result is in full agreement with the structural data, showing a clear preference for the space group $P 2_{1} / c$ for the aluminides $\mathrm{T}_{2} \mathrm{Al}_{9}$.

A similar situation is realised in the DOS of $\mathrm{Ir}_{2} \mathrm{Ga}_{9}$ (Fig. 5 , bottom). In this case, besides the $\mathrm{Ga}-\mathrm{Ga}$ bonds, bonding interactions between Ir and Ga can be derived from the overlap of Ir and Ga contributions in the valence region.
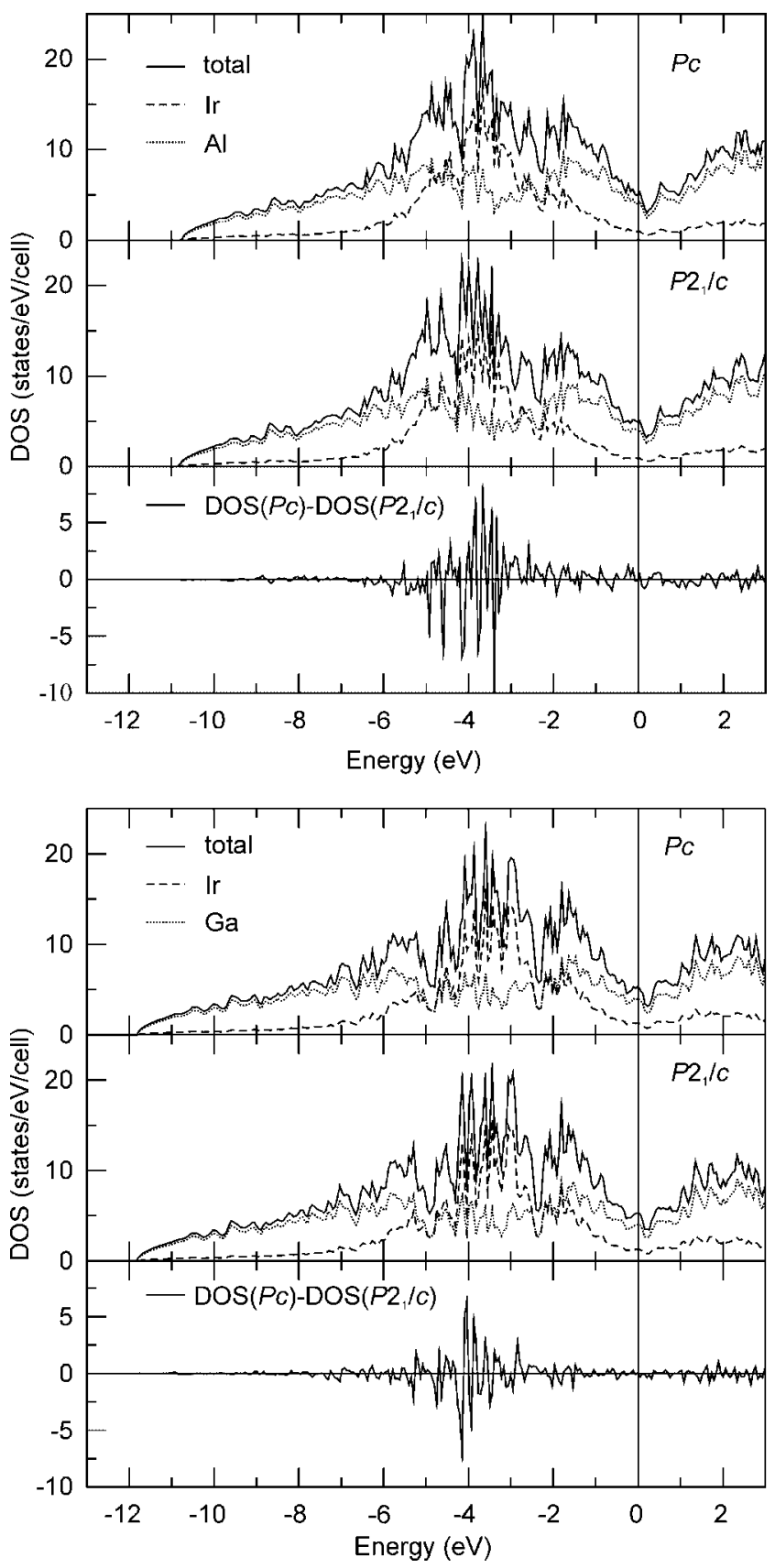

Fig. 5 Electronic density of states (DOS) for $\mathrm{Ir}_{2} \mathrm{Al}_{9}$ (top) and $\mathrm{Ir}_{2} \mathrm{Ga}_{9}$ (bottom). For both compounds the total DOS together with the contributions of Ir and $\mathrm{Al}(\mathrm{Ga})$ states are shown for both structures with the symmetry of the space groups $P c(\operatorname{DOS}(P c))$ and $P 2_{1} / c$ $\left(\operatorname{DOS}\left(P 2_{1} / c\right)\right)$. The differences between the calculations are presented in form of difference density of states $\left(\operatorname{DOS}(P c)-\operatorname{DOS}\left(P 2_{1} / c\right)\right)$.

The difference DOS reveals the largest deviation in the same region as in the case of $\operatorname{Ir}_{2} \mathrm{Al}_{9}$, but the difference is remarkably smaller in comparison with $\mathrm{Ir}_{2} \mathrm{Al}_{9}$. This fact finds its confirmation in the total energy calculation. Both symmetrically different structural variants differ in energy by only $\sim 1 \mathrm{meV}$, in favour for the $P 2_{1} / c$ variant due to the very small energy difference. This is not a direct confirmation of the structural data preferring the $P c$ variant, but 
the tendency of structural changes from $\mathrm{T}_{2} \mathrm{Al}_{9}$ to $\mathrm{T}_{2} \mathrm{Ga}_{9}$ compounds is illustrated clearly from these calculations.

Further details of the crystal structure investigation can be obtained from Fachinformationszentrum Karlsruhe, 76344 Eggenstein-Leopoldshafen, Germany, (fax. (49) 7247-808-666; e-mail: crysdata@fiz.karlsruhe.de) on quoting the depository number CSD414301 for $\mathrm{Co}_{2} \mathrm{Al}_{9}, \mathrm{CSD} 414304$ for $\mathrm{Rh}_{2} \mathrm{Al}_{9}$, CSD414302 for $\mathrm{Ir}_{2} \mathrm{Al}_{9}, \mathrm{CSD} 414305$ for $\mathrm{Rh}_{2} \mathrm{Ga}_{9}$ and CSD414303 for $\mathrm{Ir}_{2} \mathrm{Ga}_{9}$.

\section{References}

[1] A. M. B. Douglas, Acta Crystallogr. 1950, 3, 19.

[2] L. E. Edshammar, Acta Chem. Scand. 1968, 22, 2822.

[3] L. E. Edshammar. Acta Chem. Scand. 1970, 24, 1457.

[4] Binary Alloy Phase Diagrams, 2nd ed., Ed. T.B. Massalski, ASM International, Materials Park, Ohio, 1990.

[5] M. Boström, S. Hovmöller, J. Alloys Compd. 2001, 314, 154.

[6] J. Laugier, B. Bochu, CELREF, Laboratoire des Materiaux et du Génie Physique de l'Ecole Supérieure de Physique de Grenoble, France, 2003.

[7] Rigaku/MSC Inc, CrystalClear, Area detector processing software, v. 1.3.5. USA, 2002.

[8] V. Petriček, M. Dušek, Jana2000. The crystallographic computing system. Institute of Physics, Praha, Czech Republic, 2000.
[9] O. Jepsen, A. Burkhardt, O. K. Andersen, The Program TBLMTO-ASA. Version 4.7. Max-Planck-Institut für Festkörperforschung, Stuttgart, 1999.

[10] U. Barth, L. Hedin, J. Phys. 1972, C5, 1629.

[11] O. K. Andersen, Phys. Rev. 1975, B12. 3060.

[12] A. Savin, H. J. Flad, J. Flad, H. Preuss, H. G. von Schnering, Angew. Chem. 1992, 104, 185; Angew. Chem. Int. Ed. Engl. $1992,31,185$.

[13] M. Kohout, Basin. Version 2.4. Max-Planck-Institut für Chemische Physik fester Stoffe, Dresden, 2004.

[14] R. F. W. Bader, Atoms in molecules: A quantum theory, Oxford University Press, Oxford, 1999.

[15] M. Kohout, A. Savin, Int. J. Quantum Chem. 1996, 60, 875.

[16] M. Kohout, F. R. Wagner, Y. Grin, Theor. Chem. Acc. 2002, 108, 150.

[17] H. Eschrig, Optimized LCAO method and the electronic structure of extended Systems. Springer, Berlin, 1989.

[18] J. P. Perdew, Y. Wang, Phys. Rev. 1992, B45, 13244.

[19] K. Koepernik, H. Eschrig, Phys. Rev. 1999, B59, 1743.

[20] H. Flack, Acta Crystallogr. 1983, A39, 876.

[21] Y. Grin, U. Wedig, F. Wagner, H. G. von Schnering, J. Alloys Compd. 1997, 255, 203.

[22] Y. Grin, F. R. W. Wagner, M. Kohout, M. Armbrüster, A. Leithe-Jasper, U. Schwarz, U. Wedig, H. G. von Schnering, J. Solid State Chem. 2004, Submitted.

[23] P. J. Becker, P. Coppens, Acta Crystallogr. 1974, A30, 129. 